\title{
New lichen records from the Novgorod Region, Russia
}

\author{
Gulnara M. Tagirdzhanova1, Olga A. Kataeva ${ }^{2}$, Irina S. Stepanchikova ${ }^{1,2}$ \\ ${ }^{1}$ Department of Botany, St. Petersburg State University, Universitetskaya emb. 7/9, 199034 St. Petersburg, Russia. \\ ${ }^{2}$ Laboratory of Lichenology and Bryology, Komarov Botanical Institute RAS, \\ Professor Popov St. 2, 197376 St. Petersburg, Russia. \\ E-mails: gultagr@gmail.com, kataevaoa@mail.ru, stepa_ir@mail.ru
}

\begin{abstract}
Twenty lichen species are reported as new to the Novgorod Region (Russia) from Valdaysky National Park and Rdeysky Nature Reserve. Pyrenula chlorospila is recorded for the first time for European Russia outside Caucasus. Acrocordia cavata, Pertusaria coccodes, Rostania occultata and Scytinium subtile are recommended to be included in the Red Data Book of the Novgorod Region.
\end{abstract}

\section{INTRODUCTION}

The present paper comprises additions to the lichen flora of the Novgorod Region, Russia. The list of 20 new lichens is based on two collections made in two protected areas - Valdaysky National Park and Rdeysky Nature Reserve (Fig. 1). Pyrenula chlorospila is the most interesting finding, as Pyrenula spp. in general are extremely rare in the North-Western part of Russia and in Fennoscandia. The other species reported here are known from the neighboring Leningrad Region.

Valdaysky National Park is a huge (ca. 158500 hectars) heterogenous area in the eastern part of the Novgorod region (Valday, Okulovka and Demyansk Districts). The National Park includes forests $(86 \%$ of the area), lakes, swamps and rivers, agricultural landscapes, settlements and Valday town. The particularly valuable objects are the forest areas and lakes forming the natural landscape of the Valday upland. The National Park is important for regional biodiversity conservation, as well as for ecological education and tourism. The lichen diversity of Valdaysky National park has been studied from 1915 till nowadays; the existing data on lichens of the territory were summarized by the second author (Kataeva, 2002, 2004, 2010). Altogether 216 lichen species (mostly epiphytic, some epigeic and few epilithic) have been recorded from the park: 185 species are known according to the literature and additionally 31 species new to the area were collected in 2013 by the first author, 11 of them are presented in the current paper.
Rdeysky Nature Reserve $\left(57^{\circ} 01^{\prime}-57^{\circ} 23^{\prime} \mathrm{N}\right.$, $30^{\circ} 32^{\prime}-30^{\circ} 56^{\prime} \mathrm{E}$ ) is located in the southern part of the Novgorod Region (Kholm and Poddorye Districts, 36922 hectars in total). It lies on the watershed of Polist and Lovat rivers. The territory occupies the eastern part of PolistovoLovatskaya high bog system, the western part belongs to Polistovsky Reserve (Pskov Region) (Fig. 1). Polistovo-Lovatskaya high bog system is considered to be the largest in Europe (83000 hectars in total).

Rdeysky Reserve landscape is represented by continuous natural wetland with different types of peat bogs, forested islands and lakes inside the massif and surrounded by relatively undisturbed forests. The bog system occupies 33352 hectars of the reserve's square, the forest area is smaller, 3570 hectars only. The most common forest communities are mixed stands with aspen (Populus tremula L.), spruce (Picea abies (L.) Karst.) and birch (Betula spp.), spruce forests, pure alder (Alnus glutinosa (L.) Gaertn.), birch and pine (Pinus sylvestris L.) swampy forests; rarely small plots of elm forests (Ulmus spp.) occur, predominantly they are concentrated in the protective zone of the Reserve.

The protected territory has never been studied by lichenologists till the summer 2009 when the inventory of lichen diversity was started by the second author. At present the revealed lichen biota of the Reserve counts 98 species only: 87 are known from the previous studies (Kataeva, 2013) and 11 species are published here as new to the region. For sure, the existing list is 


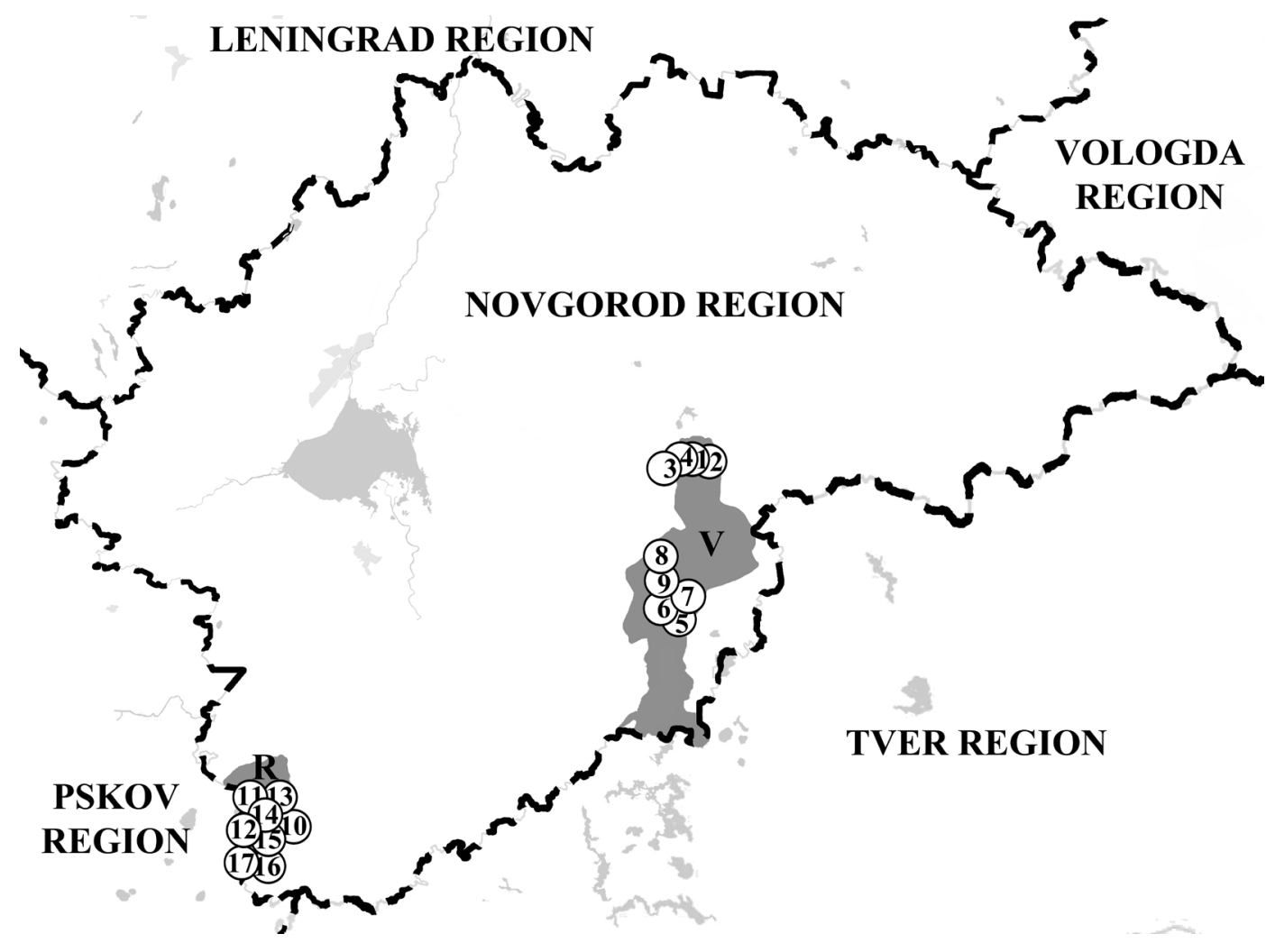

Fig. 1. Location of the collecting sites (numbers) within two natural protected areas in Novgorod Region (R - Rdeysky Nature Reserve, V - Valdaysky National Park).

not complete, and many other species are to be found in this unique area in future.

Altogether, the lichen biota of the Novgorod Region comprises today 356 species. The description of the study region in the whole and brief information on main lichenological investigations in the Novgorod Region were presented in our previous paper (Stepanchikova et al., 2013).

\section{MATERIAL AND METHODS}

The majority of the specimens were collected by G. M. Tagirdzhanova in August 2013 in Valdaysky National Park. Twelve sample plots in different parts of Valdaysky Park were examined. The lichen samples were collected from the aspen bark in the mixed spruce forests with aspen (Populus tremula L.). Additionally we revised the material collected by O. A. Kataeva on the trunks in the old-growth deciduous forests in the southern and central parts of Rdeysky Reserve.

As most of the species listed are rather common and widespread in NW Russia, Fennoscandia and Baltic countries, the distribution information is given for Pyrenula chlorospila only. The specimens are deposited in the lichen herbaria of St. Petersburg State University (LECB) and Komarov Botanical Institute in Saint Petersburg (LE). The nomenclature of taxa follows Nordin et al. (2011). Lichen substances were analyzed by using the standard technique of high performance thin-layer chromatography (HPTLC) in solvent systems A, B and C (Arup et al., 1993; Orange et al., 2001). Illustrations were made by using light microscope Carl Zeiss Axioskop 40 with camera QImaging MicroPublisher 5.0 RTV and dissecting microscope Carl Zeiss STEMI-2000 CS with camera AxioCam ICc 3. 


\section{List of localities}

Valdaysky National Park (coll. by G. M. Tagirdzhanova, 14-21.08.2013).

Okulovka District:

1) $2 \mathrm{~km}$ SW of Tuhili village, spruce forest with aspen and Vaccinium myrtillus L. $\left(58^{\circ} 14^{\prime} 59^{\prime \prime} \mathrm{N}\right.$, $\left.33^{\circ} 08^{\prime} 14^{\prime \prime} \mathrm{E}\right), 15.08 .2013$.

2) $2 \mathrm{~km} \mathrm{NE}$ of Tuhili village, peninsula Bobovik, in small lowland, spruce forest with aspen and Dryopteris filix-mas (L.) Schott. $\left(58^{\circ} 15^{\prime} 40^{\prime \prime N}\right.$, 3312'38"E), 14.08.2013.

3) $3.5 \mathrm{~km} \mathrm{SW}$ of Tuhili village, $0.5 \mathrm{~km}$ SSW of Chernoe Lake, slight slope, spruce forest with aspen and Dryopteris filix-mas $\left(58^{\circ} 14^{\prime} 46^{\prime \prime} \mathrm{N}\right.$, $\left.33^{\circ} 07^{\prime} 14^{\prime \prime} \mathrm{E}\right), 15.08 .2013$.

4) $2 \mathrm{~km} \mathrm{SW}$ of Tuhili village, spruce forest with aspen and Pteridium aquilinum (L.) Kuhn (58 $\left.15^{\prime} 08^{\prime \prime} \mathrm{N}, 33^{\circ} 08^{\prime} 28^{\prime \prime} \mathrm{E}\right), 15.08 .2013$.

Valday District:

5) $1 \mathrm{~km} \mathrm{SE}$ of Mirobuditsy village, spruce forest with aspen, Aegopodium podagraria L., Urtica dioica L. and Rubus idaeus L. (57 49 $46^{\prime} " \mathrm{~N}$, 3306'32"E), 16.08.2013.

6) NW of Mirobuditsy village (1 km), nearby the Polomet River, slight slope, spruce forest with aspen and Dryopteris filix-mas $\left(57^{\circ} 50^{\prime} 31^{\prime \prime} \mathrm{N}\right.$, $33^{\circ} 05^{\prime} 21^{\prime \prime E)}$, 17.08.2013.

7) $2 \mathrm{~km}$ NE of Mirobuditsy village, near Russkoe Lake, spruce forest with aspen and Dryopteris filix-mas (57 $\left.51^{\circ} 01^{\prime \prime} \mathrm{N}, 33^{\circ} 07^{\prime} 02 " \mathrm{E}\right), 18.08 .2013$.

8) $2 \mathrm{~km} \mathrm{NE}$ of Dvorets village, on shore of the Polomet River, spruce forest with aspen and Dryopteris filix-mas $\left(57^{\circ} 57^{\prime} 28^{\prime \prime} \mathrm{N}, 33^{\circ} 01^{\prime} \mathrm{O} 5^{\prime \prime} \mathrm{E}\right)$, 20.08.2013.

9) $1 \mathrm{~km} \mathrm{NE}$ of Krestovaya village, spruce forest with aspen, Athyrium filix-femina (L.) Roth and Dryopteris filix-mas $\left(57^{\circ} 52^{\prime} 28^{\prime \prime} \mathrm{N}, 33^{\circ} 02^{\prime} 43^{\prime \prime E}\right)$, 21.08.2013.

Rdeysky Nature Reserve (coll. by O. A. Kataeva, 24.06-27.08.2009).

Kholm District:

10) left bank of the Blizneya River $\left(57^{\circ} 11^{\prime} \mathrm{N}\right.$, $30^{\circ} 56^{\prime} \mathrm{E}$ ), 28.08.2009 (this locality is situated outside of the Reserve, but in the limits of its protective zone).

11) Osinovaya Griva island, old swampy aspen forest $\left(57^{\circ} 13^{\prime} \mathrm{N}, 30^{\circ} 48^{\prime} \mathrm{E}\right), 27.08 .2009$.
12) Bolshoe Kozhmino forest area, elm forest on margin with the swampy black alder forest $\left(57^{\circ} 07^{\prime} 39^{\prime \prime} \mathrm{N}, 30^{\circ} 44^{\prime} 52^{\prime \prime} \mathrm{E}\right), 25.06 .2009$.

13 ) the swampy aspen forest $\left(57^{\circ} 13^{\prime} \mathrm{N}, 30^{\circ} 52\right.$ ' E), 24.08.2009.

14) left bank of the Gorelka River $\left(57^{\circ} 11^{\prime} 33^{\prime \prime N}\right.$, 3050'52'E), 23.08.2009.

15) Myrtillus type aspen forest with pine, birch and fern $\left(57^{\circ} 05^{\prime} 30^{\prime \prime} \mathrm{N}, 30^{\circ} 43^{\prime} 50^{\prime} \mathrm{E}\right), 24.06 .2009$.

16) Venishnik forest area, Sphagnum-dominated peatbog with Eriophorum vaginatum L. $\left(57^{\circ} 05^{\prime} \mathrm{N}\right.$, 3044'E), 24.06.2009.

17) Sphagnum-dominated peatbog with E. vaginatum $\left(57^{\circ} 05^{\prime} \mathrm{N}, 30^{\circ} 43^{\prime} \mathrm{E}\right), 27.06 .2009$.

\section{THE SPECIES}

ACROCORDIA CAVATA (Ach.) R. C. Harris. - on bark of Populus tremula L., 5. Habitat specialist of biologically valuable forests in the Southern Taiga of North-Western European Russia (Andersson et al., 2009). We recommend this species to be included in the Red Data Book of the Novgorod Region.

ARTHONIA DISPERSA (Schrad.) Nyl. - on bark of young Acer platanoides L., 10.

BACIDIA ARCEUTINA (Ach.) Arnold - on bark of Populus tremula, 2, 7, 8, 9, 11.

BiATORA CHRYSANTHA (Zahlbr.) Printzen - on bark of Populus tremula, 4. The specimen contains gyrophoric acid.

Biatora Helvola Körb. ex Hellb. - on bark of Populus tremula, 1, 2, 6, 8, 9.

Buellia ERUBESCENS Arnold - on bark of Fraxinus excelsior L., 13.

BUELLIA GRISEOVIRENS (Turner \& Borrer ex Sm.) Almb. - on bark of Ulmus sp., 12. The specimen contains atranorin and norstictic acid.

CANDELARIELLA LUTELla (Vain.) Räsänen - on bark of Populus tremula, 6.

FuscidEA PUSILLA Tønsberg - on bark of old Betula sp., 14. The specimen contains divaricatic acid.

Gyalolechia flavorubescens (Huds.) Søchting, Frödén \& Arup [syn. Caloplaca flavorubescens (Huds.) J. R. Laundon] - on bark of Populus tremula, 11.

LECIDEA ERYTHROPHAEA Flörke ex Sommerf. - on bark of Populus tremula, 2, 6, 8.

LEPRARIA JACKII Tønsberg - on bark of Populus tremula, 1 . The specimen contains atrano- 
rin, roccellic/angardianic, jackinic/rangiformic \& norjackinic/norrangiformic acids. Mycobilimbia EPIXANTHOIDEs (Nyl.) Vitik. et al. ex. Hafellner \& Türk - on bark of Populus tremula, 1, 4, 7 .

Ochrolechia Bahusiensis H. Magn. - on bark of Populus tremula, 1, 4, 7. The specimens contain gyrophoric \& lecanoric acids and murolic acid complex (see Kukwa, 2011).

Pertusaria COCCODEs (Ach.) Nyl. - on bark of Quercus robur L., 14. The specimen contains norstictic acid. Indicator of biologically valuable forests in the Southern Taiga of North-Western European Russia (Andersson et al., 2009). We recommend this species to be included in the Red Data Book of the Novgorod Region.

PYCNORA SOROPHORA (Vain.) Hafellner. - on bark of Pinus sylvestris L., 15, 17; on lignum of Pinus sylvestris, 6 . The specimens contain alectorialic acid and related substances.

Pyrenula CHLOROSPILA (Nyl.) Arnold - on bark of old Ulmus sp., 10. The species has not been recorded in Fennoscandia, Baltic countries and European Russia outside Caucasus. The nearest locality in Russia is in the Northern Caucasus (Otte, 2005). Pyrenula chlorospila is characterized by olive-green thallus with well-developed pseudocyphellae, small and densely arranged perithecia which form low projections in the thallus, and 4-celled spores with diamond-shaped lumina (Fig. 2 A, B) (Smith et al., 2009; Aptroot, 2012). It is morphologically close to Pyrenula nitidella (Flörke ex Schaer.) Müll. Arg., but $P$. nitidella is characterized by having red, $\mathrm{K}+$ crystals inside ascomata while $P$. chlorospila has colourless crystals in exciple (the crystals were well-seen in our specimen). The material from the Novgorod Region corresponds well with the main characters of the species, but the spores are smaller: 19-22(-27) $\mu \mathrm{m}$.

ROPALOSPORA VIRIDIS (Tønsberg) Tønsberg - on bark of Populus tremula, 1, 3, 6; on bark of young Tilia sp., 11. The specimens contain perlatolic acid.

Rostania OccultatA (Bagl.) Otálora, P. M. Jørg. \& Wedin [syn. Collema occultatum var. populinum (Th. Fr.) Degel.] - on bark of old Ulmus sp., 10. Habitat specialist of biologically valuable forests in the Southern Taiga of North-Western European Russia (Andersson

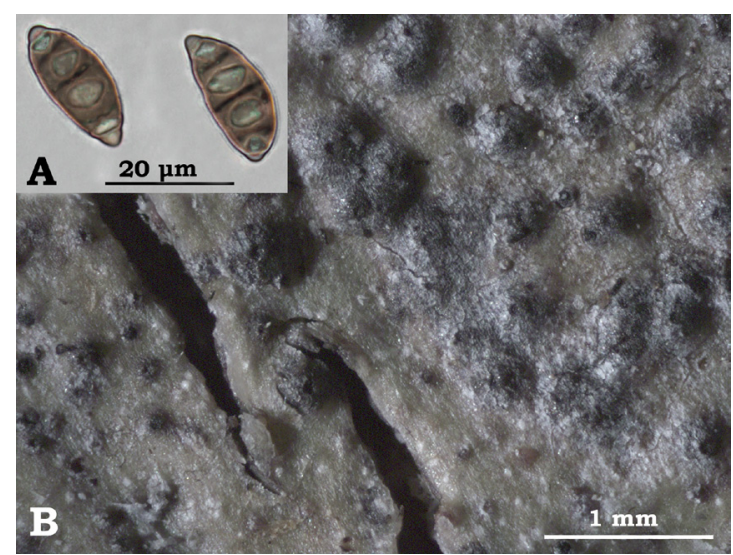

Fig. 2. Pyrenula chlorospila: A - ascospores; B - thallus with perithecia and pseudocyphellae.

et al., 2009). We recommend this species to be included in the Red Data Book of the Novgorod Region.

Scytinium subTile (Schrad.) Otálora, P. M. Jørg. $\&$ Wedin [syn. Leptogium subtile (Schrad.) Torss.] - on bark of Populus tremula, 8. In the neighboring Leningrad Region the species is rare, confined to debris on the ground in forest communities, also can be found on old concrete foundations of historical buildings, rarely on bark of old aspen trees in oldgrowth forests; red-listed in the Leningrad Region (Red..., 2000). We recommend this species to be included in the Red Data Book of the Novgorod Region.

\section{DISCUSSION}

Four species - Acrocordia cavata, Pertusaria coccodes, Rostania occultata and Scytinium subtile - are proposed to be included in the Red Data Book of the Novgorod Region. All these species were found on bark of old trees in relatively undisturbed old-growth forests. Acrocordia cavata and Rostania occultata are considered to be habitat specialists, and Pertusaria coccodes is an indicator species of old-growth forests in North-Western European Russia (Andersson et al., 2009). Focused ecological specialization of these species suggests that in the Novgorod Region, where forests are heavily managed in general, such lichens are extremely rare due to anthropogenic transformation of biotopes. 
Scytinium subtile can be found on wet calcareous stones; in Leningrad Region it was found a few times on old foundations in historical parks. However, the species has never been recorded in the Novgorod Region in such habitats.

Based on the current data, all the four species can be classified as critically endangered according to IUCN criterion B.1.a - "severely fragmented or known to exist at only a single location" and, taking in account active cuttings in the Novgorod Region, also B.2.b.ii - "Continuing decline... in... area of occupancy" (IUCN..., 2012).

\section{ACKNOWLEDGEMENTS}

The authors wish to express gratitude to Dr. Elena M. Litvinova and other staff members of Valdaysky National Park and Dr. Nicolay A. Zavyalov (Rdeysky Nature Reserve) for organizing the field work. We are grateful to Dmitry E. Himelbrant for consultations, Julia V. Gerasimova for revising the specimens of Bacidia arceutina and anonymous Reviewer for improvement of the manuscript. We also would like to thank all our colleagues who participated in the field trips. The study was funded by the Russian Foundation for Basic Research (grant 14-04-01411), Saint-Petersburg State University (research grant 1.37.151.2014), RSCF grant 14-24-00037 and by the Program of Basic Research of the Presidium of RAS "Wildlife: Current Status and Problems of Development".

\section{REFERENCES}

Andersson, L., Alexeeva, N. \& Kuznetsova, E. (eds). 2009. Survey of biologically valuable forests in North-Western European Russia. Vol. 2. Identification manual of species to be used during survey at stand level. (In Russian). St. Petersburg. 258 pp.

Aptroot, A. 2012. A world key to the species of Anthracothecium and Pyrenula. Lichenologist 44: 5-53. http://dx.doi.org/10.1017/S0024282911000624

Arup, U., Ekman, S., Lindblom, L. \& Mattsson, J.-E. 1993. High performance thin layer chromatography (HPTLC), an improved technique for screen- ing lichen substances. Lichenologist 25: 61-71. http:/ /dx.doi.org/10.1017/S0024282993000076

IUCN Red List categories and criteria. Version 3.1. Second edition. IUCN, Gland. 32 pp.

Kataeva O. A. 2004. Diversity of lichen species in forest communities of the National Park "Valdaysky" (Novgorod Region). Forests of Eurasia - Eastern Carpathians. Proceedings of IV International conference of young scientists in honor of the academician P. S. Pogrebnyak. (In Russian). Moscow, pp. $157-159$.

Kataeva O. A. 2010. Some results and prospects of lichen biota studies in the National Park "Valdaysky". In: Litvinova E. M. (Ed.). Scientific studies in the National Park "Valdaysky": jubilee volume dedicated to the 20-th anniversary of "Valdaysky" national park foundation. (In Russian). Vol. 1. SPbGUTD, St. Petersburg, pp. 289-294.

Kataeva, O. A. 2013. To the lichen studies in Rdejsky Reserve. In: Proceedings of Rdejsky State Natural Reserve. (In Russian). Issue 2. Veliky Novgorod, pp. 4-17.

Kataeva O. A. (Katenina). 2002. Lichen species of Novgorod Region. (In Russian). Novitates Systematicae Plantarum non Vascularium 36: 114-143.

Kukwa, M. 2011. The lichen genus Ochrolechia in Europe. Fundacja Rozwoju Uniwersytetu Gdańskiego, Gdańsk. 309 pp.

Nordin, A., Moberg, R., Tønsberg, T., Vitikainen, O., Dalsätt, Å., Myrdal, M., Snitting, D. \& Ekman, S. 2011. Santesson's Checklist of Fennoscandian Lichen-forming and Lichenicolous Fungi. Version April 29, 2011 - http:/ / 130.238.83.220/santesson/home.php (20 March 2014).

Orange, A., James, P. W. \& White, F. J. 2001. Microchemical methods for the identification of lichens. British Lichen Society. 101 pp.

Otte, V. 2005. Notes on the lichen flora of the Black Sea coast of Russia. (In Russian). Novitates Systematicae Plantarum non Vascularium 39: 219-224.

Red Data Book of Nature of Leningrad Region. Vol. 2. Plants and Fungi. 2000. (In Russian). St. Petersburg. 672 pp.

Smith, C. W., Aptroot, A., Coppins, B. J., Fletcher, A., Gilbert, O. L., James, P. W. \& Wolseley, P. A. (eds). 2009. The lichens of Great Britain and Ireland. The British Lichen Society, London, pp. 931-957.

Stepanchikova, I. S., Gagarina, L. V. \& Kataeva, O. A. 2013. New records of lichens and allied fungi from the Novgorod Region, Russia. Folia Cryptogamica Estonica 50: 49-55. http:/ /dx.doi.org/10.12697/ fce.2013.50.07 
108 Folia Cryptog. Estonica 